\title{
Setup, efforts and practical experiences of a monitoring program for genetically modified plants - an Austrian case study for oilseed rape and maize
}

Kathrin Pascher ${ }^{1,2^{*}}$, Dietmar Moser ${ }^{3}$, Stefan Dullinger ${ }^{1,3}$, Leopold Sachslehner ${ }^{4}$, Patrick Gros ${ }^{5}$, Norbert Sauberer ${ }^{3}$, Andreas Traxler ${ }^{6}$, Georg Grabherr ${ }^{1}$, Thomas Frank ${ }^{2}$

\begin{abstract}
Background, aim and scope: According to the Directive 2001/18/EC, genetically modified plants [GMPs] have to be monitored for unintended ecological impacts during their release. Detrimental effects on the biodiversity of agro-ecosystems represent a prime focus of such a monitoring. Although cropping of GMPs has already been permitted in the European Union, the establishment of appropriate monitoring networks lags behind. Here, we provide an overview on Biodiversity-Nature-Safety [BINATS], one of the first national monitoring programs specifically designed and implemented to accompany and survey GMP effects on the biodiversity of agricultural landscapes.
\end{abstract}

Materials and methods: BINATS was implemented on 100 test areas $(625 \mathrm{~m} \times 625 \mathrm{~m}$ ) which were selected based on a stratified random sampling design from all across the Austrian agricultural landscape with a focus on maize and oilseed rape cultivation. For each test area, the distribution of different habitat structures was mapped, and the species number of vascular plants, the species number and abundance of butterflies and grasshoppers, as well as the abundance of potential hybridisation partners of oilseed rape were recorded on ten randomly distributed sampling sites (circles, radius $20 \mathrm{~m}$ ).

Results and conclusions: Implementing BINATS resulted in a consistent database of the biodiversity and habitat configuration across parts of the Austrian agricultural landscapes. These data provide a baseline against which future biodiversity trends and their relationship with eventual GMP cropping can be evaluated. Moreover, they serve for assessing site-specific biodiversity-related risks of GMP cropping even in advance of their release. Finally, the first monitoring cycle (2007 and 2008) revealed insights into both the significance and the limits of such a monitoring program and allowed for a realistic calculation of the associated costs.

Recommendations and perspectives: Regular reassessments of the BINATS network will provide valuable insights into the change of biodiversity in Austrian agricultural landscapes and their potential drivers. BINATS was specifically designed to collect such information at comparatively low costs. However, the BINATS approach is flexible enough to include additional indicators or monitoring objects to take account for future insights into their particular relevance in a GMP cropping context. The results obtained from the first BINATS cycle could not yet be correlated with GMP impacts since GMPs have not been commercially released in Austria so far. In this aspect, BINATS still needs to prove its suitability to relate biodiversity changes to GMP cropping. But it is

\footnotetext{
* Correspondence: kathrin.pascher@univie.ac.at

'University of Vienna, Department of Conservation Biology, Vegetation

Ecology and Landscape Ecology (CVL), Rennweg 14, A-1030 Vienna, Austria

Full list of author information is available at the end of the article
} 
intended to repeat the survey of the BINATS data in regular reassessments to improve our knowledge about the general biodiversity trends in agricultural landscapes free of GMP cropping. These baseline data should help to relate GMP-specific effects on biodiversity in future.

\section{Background, aim and scope}

After admission by the EU Commission, genetically modified plants [GMPs] have to be monitored during their release in order to detect adverse effects of these crops or their use on the environment. Such a monitoring procedure is part of the precautionary principle of GMP cropping and is mandatory according to the Directive 2001/18/EC [1]: 'Case-specific monitoring serves to confirm that scientifically sound assumptions, in the environmental risk assessment, regarding potential adverse effects arising from a genetically modified organism [GMO] and its use are correct. General surveillance is largely based on routine observation ("look see" approach) and should be used to identify the occurrence of unforeseen adverse effects of the GMO or its use for human health and the environment that were not predicted in the risk assessment [2]'.

The UK's Farm Scale Evaluations demonstrated that reductions in species abundances across various taxa and diversity of agro-ecosystems may be adverse effects of GMP cropping, though indirectly through the use of broad-spectrum herbicides [e.g. [3-5]. Monitoring the status of biodiversity should hence be a prime issue within any monitoring program accompanying the release of GMPs. Such a monitoring program of GMPrelated biodiversity trends should basically provide [6-9]: (1) a set of test areas representative of the range of soil types, climatic conditions and management regimes of a country; (2) baseline data necessary for detecting changes in the abundance and diversity of plants and animals as well as in habitat structures over time; and (3) time series data for describing general trends of biodiversity in agricultural environments, independent of GMP cropping. Following implementation, such a monitoring network will allow for (1) a first risk assessment for GMP release by providing information on the spatial distribution of biodiversity as well as on the occurrence and abundance of GMP-related species that might eventually serve as bridges catalyzing the escape of transgenes and (2) the detection of GMP-specific effects on biodiversity by comparing trends in landscapes that are or are not affected by the release of modified crops.

Biodiversity is an extremely complex phenomenon [10] and its comprehensive measurement, hence, hardly feasible e.g. [11]. Thus, a basic decision in developing a biodiversity-related monitoring program concerns the selection of appropriate indicators for evaluating regional variation and temporal trends of certain biodiversity components [12]. Within a GMP monitoring program, such indicators should best represent larger functional groups (e.g. primary producers, herbivores, pollinators) that correlate with the diversity of as much not surveyed taxonomic groups as possible. Moreover, they should respond sensitively and rapidly to changes in environmental conditions or management regimes of agricultural landscapes. Ideally, they should also be of particular relevance to the GMP issue due to specific hypothesised risks [13]. Current knowledge on crosstaxon correlations as well as on taxon-specific sensitivities and GMP-related risks is by no means complete [e.g. [14-17]]. Hence, methodological flexibility which allows for future incorporation of additional indicators represents an important further requirement to a sound GMP monitoring program.

Finally, periodical reassessments are a key to any monitoring program. In order to serve its purpose, future funding of reevaluation efforts should hence be backed by basing the program's design and implementation on sound cost/benefit calculations. Currently, no concrete data on necessary efforts are available, however, as most relevant monitoring programs have not reached the stage of implementation yet. There is hence an urgent need for such information as the release of the first two GMPs - Bt maize Mon810 and GM potato [Solanum tuberosum L. line EH92-527-1; [18] - is already permitted in the European Union and implemented in a couple of EU Member States [19].

In this paper, we exemplify the general requirements on a biodiversity monitoring program related to GMP cropping by presenting an overview on the Austrian Biodiversity-Nature-Safety [BINATS] project [8,9]. BINATS has been implemented between 2006 and 2009 and is mainly applicable for general surveillance. Casespecific monitoring is based on a hypothesis of an already observed effect within the environmental risk assessment and needs a more specific monitoring. However, the BINATS data in this case could provide at least additional essential background information.

The choice of oilseed rape - besides maize - as a candidate for BINATS was requested by the two commissioning Austrian Ministries. Actually, GM oilseed rape is permitted in the EU only for placing on the market for import (viable GMO). A notification for the cultivation of GM oilseed rape in the European Union has been rejected within the EU in 2005. This has been a case-by-case decision, and there is no guarantee that in 
the future notifications seeking for approval of cultivation will not be applied. Nevertheless, a basic consensus but no 'official agreement' within the Member States exists that cultivation of oilseed rape should be avoided due to unpredictable environmental risks. Hence, data about the occurrence and frequency of potential hybridisation partners of oilseed rape were collected within BINATS to allow for a coarse regional assessment of the risks involved in releasing a GM crop with that high potential for hybridisation and long viability of seeds. These data could also serve at least as background information in connection with an eventual import of GM oilseed rape seeds. Seed lots during transport activities may result in persisting feral oilseed rape populations e.g. [20-27], which are also able to exchange transgenes with wild species sexually compatible with them.

At last, the efforts taken and problems encountered during the first monitoring cycle in 2007 and 2008 are discussed and provide information relevant for appropriate cost/benefit estimations. The data compiled during the implementation of BINATS do not only provide baseline data for a GMP monitoring but also represent the starting point of a permanent biodiversity observation network across the Austrian agricultural landscapes.

\section{Methods}

\section{Selection of indicators}

First of all, criteria had to be defined which constitute an organism group as a good indicator for the special requirements of the BINATS monitoring program [11] 11 , see above. We searched for indicators which should provide broad information concerning the test circle as well as the adjacent situation. All selected organism groups should occur in high species richness and abundance in agricultural landscapes to be able to detect potential changes on species and individual numbers related to GMPs. One animal group should show a broad functional claim. It should have a direct connection to cultivated areas as well as a broad spectrum of dietary habits.

Meanwhile, the survey of habitat structures is a standard in biodiversity recording programs. The diversity of habitat structures is highly correlated with the diversity of certain groups of organisms e.g. [28,29] and was even observed to affect both oilseed rape pests and their antagonists [30-32]. This parameter can be assessed for the whole test area with comparatively low cost and time effort. An essential claim on an indicator is its representativeness for other taxa. Although cross-taxon correlation is still discussed controversially e.g. [33-35], Sauberer et al. [36] demonstrated in an Austrian crosstaxon study of eight different taxonomic groups that vascular plants and grasshoppers were good predictors for the other observed taxa. Vascular plants as well as grasshoppers - no need of traps, no labour work, nondestructive sampling, visual and/or acoustical identification - are easy to assess and are cost-efficient. Butterflies were chosen because butterfly schemes are widely used in environmental monitoring programs, making them good candidates as suitable indicators [15,37-41]. Lepidoptera are well known, they have short regeneration stages which make them suitable as an early warning system, and they are an accepted aim of protection. Moreover, there are specific GMP risk hypothesis for this indicator, for instance for Bt maize, like the affected caterpillar development resulting from consuming deposited GM maize pollen on their fodder plants [42-46]. Moreover, butterfly richness and functional groups are appropriate for characterising different habitat structures in the agricultural landscape [47].

Besides scientific considerations, practical reasons also played an important role for the final choice of the four indicators, like practicability of the survey and comparatively easy and quick determination of species, availability of experts being easily trained for the BINATS survey, applicability in a long-term monitoring and high methodological acceptance by farmers, e.g. waiving of using pitfall traps.

However, our indicator set is somewhat incomplete. Especially, ground-dwelling taxa and soil organisms (e.g. carabids, spiders, mites, collembols, etc.) are neglected so far. Despite their importance and value as indicator groups, we were unfortunately not able to incorporate these taxa in the first run of BINATS due to financial reasons. Especially, taxa like carabid beetles or spiders are expensive. Determination is time-consuming and standard methods for collection use pitfall traps with all its implications. Trapping is invasive and needs much more coordination with the farmers to get permissions and avoid intended or unintended destruction. But BINATS was designed in a way that additional indicators like soil-related taxa can easily be integrated. An extension of the indicator set is claimed for further inventories.

\section{Selection, size and spatial position of the BINATS test areas}

We used a stratified random sampling procedure for selecting test areas for monitoring biodiversity in the Austrian agrarian regions $[8,9,48]$. For reasons of compatibility, we matched the biodiversity monitoring network to the grid of the Austrian Forest Inventory (ÖWI) and to the EEA reference grid http://www.eea. europa.eu/data-and-maps/data/eea-reference-grids which is used as the standard reference grid for all spatial statistic data in Austria. Hence, we have a direct spatial link between our BINATS test areas and a wide range of socioeconomic and agronomic statistics, provided by 
Statistic Austria and the Austrian Federal Ministry of Agriculture, Forestry, Environment and Water Management (Integrated Administration and Control System [IACS]). The cell size of the biodiversity monitoring grid was set to $625 \mathrm{~m} \times 625 \mathrm{~m}$ (see Table 1 ).

As the biodiversity monitoring program is focused on agrarian ecosystems, we restricted the area of interest to grid cells with $<20 \%$ forests and settlement areas. Because we were assigned to set up a monitoring network for the oilseed rape and maize cropping areas, the area of interest was moreover restricted to areas exceeding $1 \%$ of oilseed rape and maize regional acreage during the period from 2002 to 2005, respectively, based on the database of IACS. These restrictions resulted in a total of 1,144 grid cells $(625 \mathrm{~m} \times 625 \mathrm{~m})$ for oilseed rape and 1,568 grid cells for maize.

For the stratification procedure, we chose five variables which had been proven to be good predictors of agrarian biodiversity. They are supposed to be the basic variables which control biodiversity patterns. We were restricted, however, to variables which were available for the whole area of interest.

\section{The five stratification variables were}

-Diversity of soil types

-Forest cover in close proximity of the $625 \mathrm{~m} \times 625 \mathrm{~m}$ test area

-Grassland cover

-Average annual temperature

-Average annual precipitation

Spatial layers of these variables were intersected with our sample grid in a geographic information system [GIS], and the grid cells were clustered with a K-means cluster algorithm into ten clusters (all statistical and GIS analyses were done in $\mathrm{R}$ and ArcGis, respectively). On a first pass, we selected $2 \times 65$ test areas - for the maize and oilseed rape cropping area each - which were inspected visually on aerial photographs to check if they met the requirements (i.e. $<20 \%$ forests and settlement areas). Moreover, all involved farmers were asked to grant permission for monitoring on their land. Denied access and rejecting of test areas with $>20 \%$ of forests accounted for a rejection rate of about $30 \%$ and resulted in a final selection of $2 \times 50$ BINATS test areas.

Table 1 Methods of the BINATS survey of the indicator groups habitat structures, vascular plants, butterflies, and grasshoppers [48]

\begin{tabular}{|c|c|c|c|c|}
\hline & Habitat structures & Vascular plants & Butterflies & Grasshoppers \\
\hline Transect cross & - & $20 \mathrm{~m}$ (length) $\times 2 \mathrm{~m}$ (width) $\times 4$ (transect axes) & $\begin{array}{l}20 \mathrm{~m} \text { (length) } \times 5 \mathrm{~m} \\
\text { (width) } \times 4 \text { (transect } \\
\text { axes) }\end{array}$ & $\begin{array}{l}10 \text { m (length) } \times 5 \text { m (width) } \times \\
4 \text { (transect axes) }\end{array}$ \\
\hline $\begin{array}{l}\text { Surveyed } \\
\text { area/transect } \\
\text { cross }\end{array}$ & - & $160 \mathrm{~m}^{2}$ & $400 \mathrm{~m}^{2}$ & $200 \mathrm{~m}^{2}$ \\
\hline $\begin{array}{l}\text { Surveyed area } \\
\text { per test area }\end{array}$ & $625 \mathrm{~m} \times 625 \mathrm{~m}$ & $1,600 \mathrm{~m}^{2}$ & $4,000 \mathrm{~m}^{2}$ & $2,000 \mathrm{~m}^{2}$ \\
\hline \multirow[t]{2}{*}{$\begin{array}{l}\text { Date of } \\
\text { inquiry }\end{array}$} & $\begin{array}{l}\text { Beginning of April until } \\
\text { the end of October }\end{array}$ & Spring: 15.04. until 31.05. & $\begin{array}{l}\text { Middle of July until } \\
\text { middle of August ( } 9 \\
\text { A.M. until } 5 \text { P.M.) }\end{array}$ & $\begin{array}{l}\text { Middle of July until end of } \\
\text { August (9 A.M. until } 7 \text { P.M.) }\end{array}$ \\
\hline & & Summer: 01.08. until 30.09. & & \\
\hline $\begin{array}{l}\text { Number of } \\
\text { inquiries }\end{array}$ & 1 & 2 & 1 & 1 \\
\hline $\begin{array}{l}\text { Time for } \\
\text { survey }\end{array}$ & $\begin{array}{l}\text { Unlimited: complete } \\
\text { compilation }\end{array}$ & Unlimited: complete compilation & $\begin{array}{l}\text { Max. walking pace: } 3 \\
\mathrm{~km} / \mathrm{h} \text {, additional } 5 \\
\text { min survey }\end{array}$ & $8 \mathrm{~min} / 10 \mathrm{~m}$ transect \\
\hline $\begin{array}{l}\text { Used } \\
\text { literature for } \\
\text { determination }\end{array}$ & $\begin{array}{l}\text { Red Data Book of the } \\
\text { Austrian endangered } \\
\text { biotopes [50-53] }\end{array}$ & Austrian Excursion Flora [64] & $\begin{array}{l}\text { Butterfly field guides } \\
\text { [65-67] }\end{array}$ & $\begin{array}{l}\text { Grasshopper field guides } \\
\text { [68-71], grasshopper sound } \\
\text { recordings (Panrok, } \\
\text { unpublished) }\end{array}$ \\
\hline \multirow[t]{2}{*}{$\begin{array}{l}\text { Temperature } \\
\text { thresholds }\end{array}$} & None & None & $\begin{array}{l}\text { Min. temperature: } \\
13^{\circ} \mathrm{C}\end{array}$ & Min. temperature: $20^{\circ} \mathrm{C}$ \\
\hline & & & $\begin{array}{l}\text { Max. temperature: } \\
36^{\circ} \mathrm{C}\end{array}$ & \\
\hline $\begin{array}{l}\text { Subjects of } \\
\text { inquiry }\end{array}$ & $\begin{array}{l}\text { Type, location and } \\
\text { number of habitat } \\
\text { structures in the whole } \\
\text { test area }\end{array}$ & $\begin{array}{l}\text { Species number separately within each habitat } \\
\text { structure, abundance of potential hybridisation } \\
\text { partners of oilseed rape on an ordinal scale }\end{array}$ & $\begin{array}{l}\text { Species number and } \\
\text { abundance }\end{array}$ & $\begin{array}{l}\text { Species number and } \\
\text { abundance }\end{array}$ \\
\hline $\begin{array}{l}\text { Additional } \\
\text { recording of }\end{array}$ & $\begin{array}{l}\text { Hybridisation partners of } \\
\text { oilseed rape and beets }\end{array}$ & Habitat structures within the transect cross & $\begin{array}{l}\text { Habitat structures } \\
\text { and vegetation, } \\
\text { floral visits }\end{array}$ & $\begin{array}{l}\text { Habitat structures and height } \\
\text { of vegetation }\end{array}$ \\
\hline
\end{tabular}


The number of test areas $(625 \mathrm{~m} \times 625 \mathrm{~m}$, see Table 1$)$ to be sampled was subject to opposite constraints, as is probably the case in most monitoring programs of that kind: On the one hand, the statistical power achievable with the data to be sampled should be maximised, and on the other hand, the financial budget available was $a$ priori limited. To find a reasonable compromise between these two constraints, we conducted power analyses and evaluated the number of test areas necessary to achieve statistical significance (1) when comparing the same plots sampled at two different points of time in terms of species richness and (2) when correlating changes in species richness with changes in numerical co-variables (like the proportional area of GMPs per test area; Figure 1). In both cases, we assumed that the target power of the tests with the sampled data should conform to the standard of 0.8 (i.e. a $20 \%$ probability of a type II error) and that tests will be conduced to evaluate one-sided hypotheses (either of a difference in species richness $<0$, i.e. a loss of species over time evaluated by a paired $t$ test, or of a correlation coefficient $>0$ ). The necessary estimates of the expected variance in species richness across areas were derived from a prior project on biodiversity patterns in Austrian agricultural landscapes [36]. Based on the results of this analysis, we decided to use a sample of 100 test areas as a reasonable compromise between the test power and the available budget [49].

\section{Methods of survey}

For practical reasons, we used a combination of a random point and a transect sampling setup for collecting biodiversity data: Ten circles with a radius of $20 \mathrm{~m}$ were randomly distributed within each test area. Within each circle, species data were assessed along a $40 \mathrm{~m}$ north/ south and a $40 \mathrm{~m}$ east/west transect cross (Figure 2). Compared to a transect approach, the point sampling approach proved to be more practicable in terms of field work efficiency - it is easier to locate a circle than to follow a predefined transect across the whole study area - provokes fewer conflicts with land owners and provides more representative data with equal efforts. In contrast to a habitat-specific approach, the constant sampling size standardises sampling intensity and, hence, avoids sampling bias.

Species numbers of vascular plants, species numbers and abundance of butterflies and grasshoppers, and the abundance of potential hybridisation partners of oilseed rape were recorded along the ten test circles (see Figure 2 and Table 1). Animal indicators were recorded once, in the middle of summer. Vascular plants were recorded twice, in spring and late summer. Separate species were collected for each single habitat within the cross transects.

Habitat classification followed the Red Lists of Austrian Endangered Biotopes [50-53] which were simplified for the requirements of BINATS. The habitat structure mapping comprised the whole test areas and was conducted by a field survey using aerial photographs for marking the exact location of the recorded habitat structures. Field maps were digitised and stored in a GIS.

\section{Results}

\section{Species diversity}

Altogether, exact 900 vascular plant species - nearly one third of the entire Austrian flora - were detected across
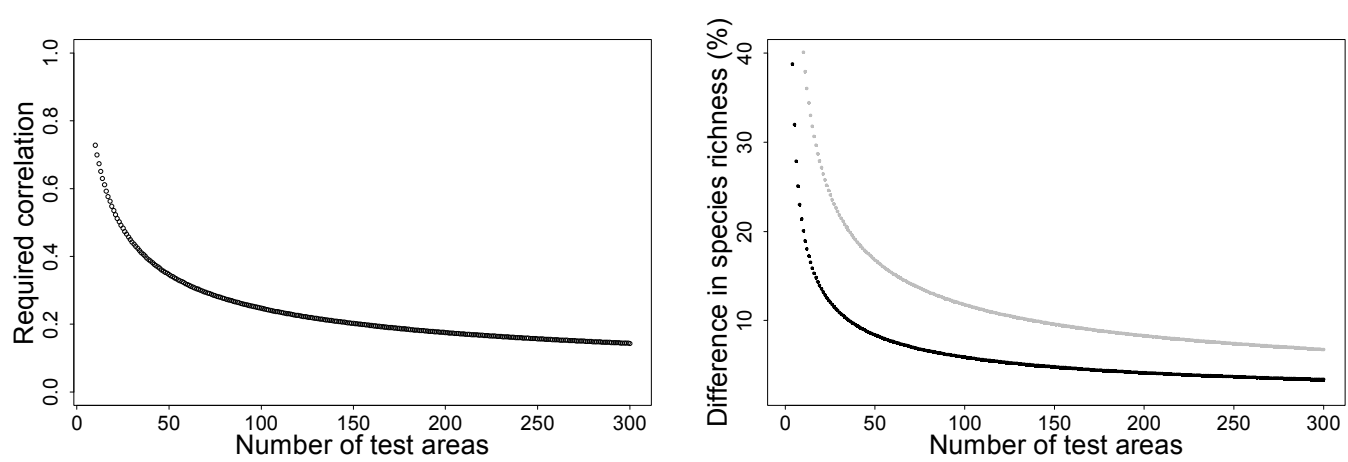

Figure 1 Power analysis results. The Power analysis relates the number of test areas to the actual effect size which a Pearson productmoment correlation test (a) (left panel) or a $t$ test (b) (right panel) would identify as significant (at a $p$ level of 0.05). Effect sizes are either correlations between species numbers and a numerical predictor variable (e.g. proportional area of GMP fields) or differences in species numbers between two sets of $n$ test areas. We assumed that the required power of the test is 0.8 (i.e. a type II error probability of 0.2 ) and that significance is tested for the one-sided hypotheses of a correlation coefficient $>0$ (left panel) and a loss of species over time on the same plots (paired test of species number at time point 1 < species number at time point 2). The grey (standard deviation = 40 species) and black (standard deviation $=20$ species) lines in the right panel represent different assumptions on the variance of species numbers across test areas as derived from precursor Austrian projects [e.g. [36]]. 


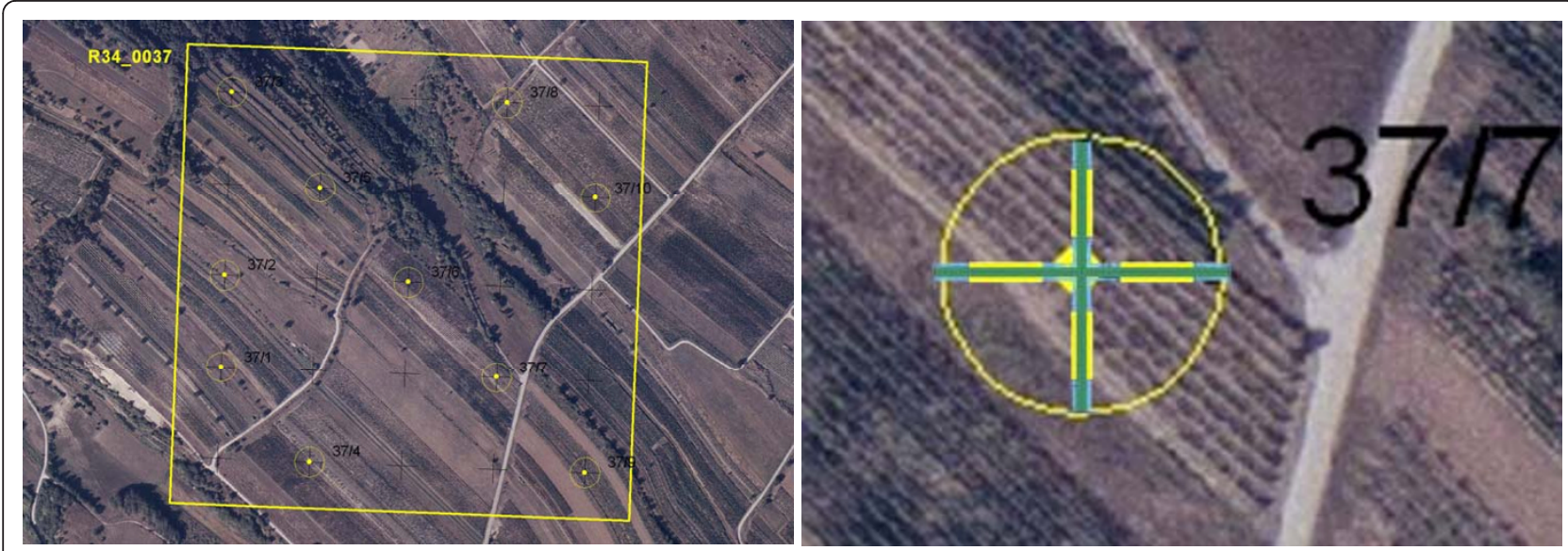

Figure 2 BINATS monitoring design of a combination of a random point and a transect sampling setup. For biodiversity data collection, ten test circles with a radius of $20 \mathrm{~m}$ were randomly distributed within each test area $(625 \mathrm{~m} \times 625 \mathrm{~m})$. Species data were assessed along a $40 \mathrm{~m}$ north/south and a $40 \mathrm{~m}$ east/west transect cross

all 100 BINATS test areas during the first survey circle in 2007 and 2008. More than $11 \%$ of these are listed as endangered in the Austrian Red List [54]. Fifty-three different species of grasshoppers (among these are 21 endangered species) and 41 different butterfly species (among these are nine endangered species) were found. Vascular plant numbers per test area varied between 212 and 22 species. Grasshopper species number varied between 21 and 1 per test area, and butterflies showed a maximum of 15 species and a minimum of none. On $29.9 \%$ and $58.3 \%$ of the test circles, respectively, no grasshopper and butterfly species could be detected. The number of different habitat structures per test area varied between 4 and 38, with a maximum of 299 single-habitat patches per test area. The maps in Figure 3 show the distribution of the 100 BINATS test areas with varying numbers of species for vascular plants (a), grasshoppers (b) and butterflies (c).

\section{Most frequent species of the taxonomic indicators}

The most frequent vascular plant species was the white goosefoot (Chenopodium album agg.) which was found in 587 of 1,000 test circles, followed by the common chickweed (Stellaria media, 518 detections) and the creeping thistle (Cirsium arvense, 501 detections). The most frequent grasshopper species was Chorthippus biguttulus (bow-winged grasshopper, 188 detections), and amongst butterflies, Pieris rapae (small white, 170 detections) was detected most frequently.

\section{Ecological risk assessment}

Based on the occurrence and abundance of potential hybridisation partners in Austria [55,56], a first ecological risk assessment of GM oilseed rape was performed. Feral populations or volunteers of oilseed rape were found in nearly three quarters (71 out of 100) of all BINATS test areas. On average, oilseed rape could be recorded within 2.41 circles per test area. In eight test areas $(8 \%)$, feral oilseed rape populations were observed along transport routes, which confirms earlier findings that spillage during transport plays an important role for the establishment of feral oilseed rape populations (see above).

Figure 4 shows the species numbers (a) and individual numbers (b) of potential hybridisation partners of oilseed rape within the 100 BINATS test areas. The highest species number and the highest abundance of potential hybridisation partners of oilseed rape were determined for the Pannonian Region. Additionally, four locations of weed beets are marked in Figure 4, which are sexually compatible with cultivated beets. Two of them are directly located in the Austrian seed production areas of beets; the others on the border of Austria to Slovakia.

Maize plants outside fields were detected in Burgenland (Pascher, in preparation). Their existence probably traces back to a spillage event during feeding of wild game. Hence, the existence of fertile maize plants outside cropping fields could be relevant for the coexistence of genetically modified, conventional and organic maize even in Central Europe.

Comparing the vascular plant species numbers from large-scale surveys (sampling areas about $35 \mathrm{~km}^{2}$ ), like the floristic mapping of Austria [57], or derived indices [58], with the species number of the BINATS test areas revealed only a marginal correlation of diversity patterns across scales. This finding underlines that the assessment of biodiversity-related GMP risks based on large spatial scale $\left(35 \mathrm{~km}^{2}\right)$ data might not provide reliable results in fine-grained agricultural landscapes. Thus, a 

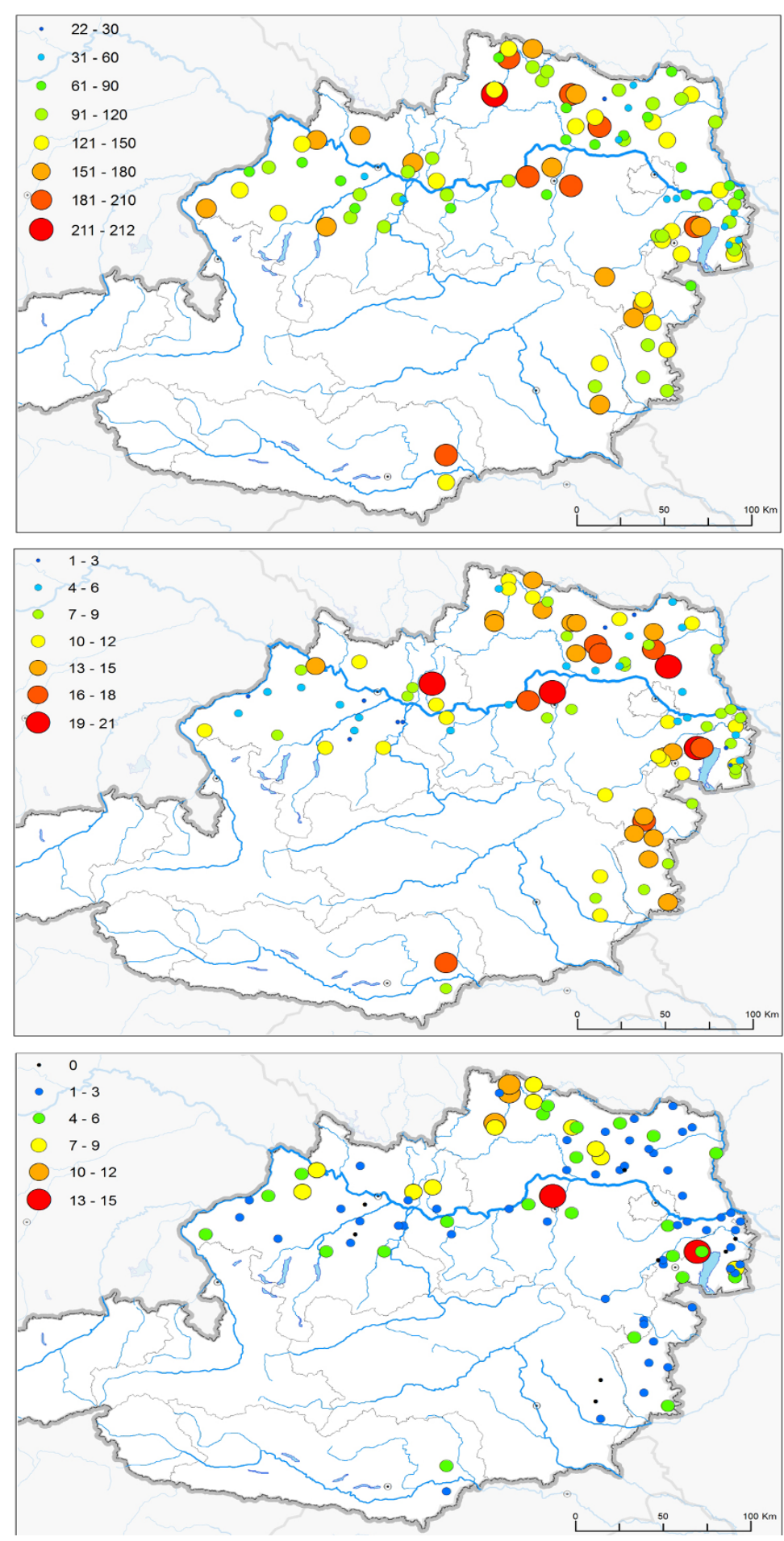

Figure 3 Species numbers recorded in the BINATS test areas. (a) Vascular plants, (b) grasshoppers, and (c) butterflies. All 100 test areas are assigned to a symbol differing in colour and size according to species richness. Notice the comparatively large number of small spots on the butterfly map which indicate that no butterfly species was found in these test areas. 

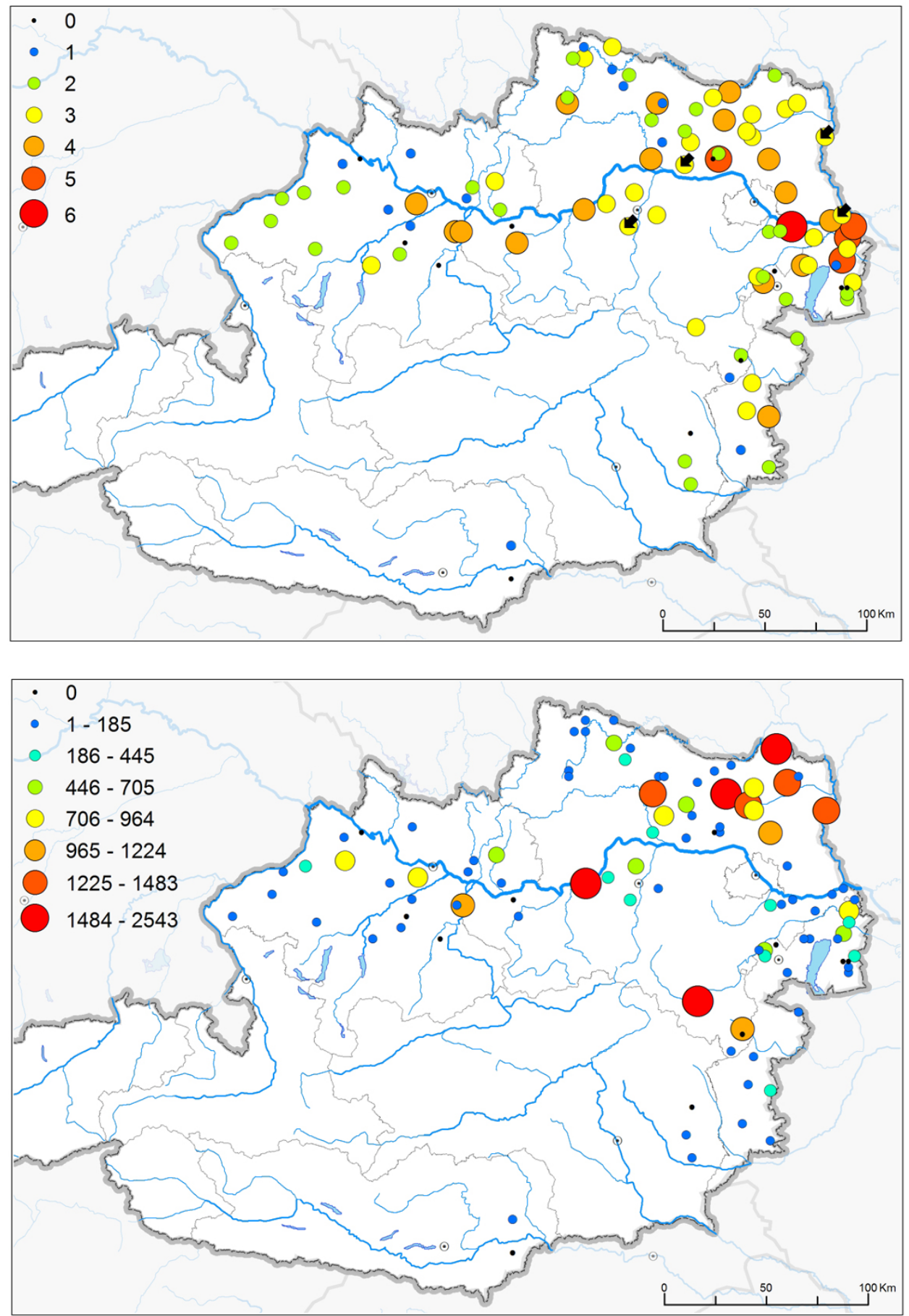

Figure 4 Species numbers and abundance of potential hybridisation partners of oilseed rape [OSR]. The location of the 100 BINATS test areas is indicated with symbols. Different sizes and colours refer to the listed species numbers (a) or abundance of species (b) sexually compatible to oilseed rape in Austria $[55,56,63]$. The following related species were considered for the calculation: Brassica elongata, B. juncea, feral B. napus, B. nigra, feral B. oleracea, wild and feral B. rapa, Conringia austriaca, C. orientalis, Crambe tatarica, Diplotaxis muralis, D. tenuifolia, Eruca sativa, Erucastrum gallicum, E. nasturtiifolium, Hirschfeldia incana, Raphanus raphanistrum, wild and feral R. sativus, Rapistrum perenne, R. rugosum, Sinapis alba, S. arvensis, Sisymbrium altissimum, S. austriacum, S. irio, S. loeselii, S. officinale, S. orientale, and S. strictissimum. (a) Number of recorded species (see list above) in each BINATS test area closely related to OSR and occurrence of weed beets. The four registered locations of weed beets (black arrows) sexually compatible with the crops fodder and sugar beet are also indicated in this map. (b) Abundance of species closely related to OSR observed in each BINATS test area using a logarithmic estimation scale during field work. Colours and sizes of symbols refer to the listed individual numbers on this map. 
small-scale survey $\left(0.39 \mathrm{~km}^{2}\right)$ as performed in BINATS is mandatory for the evaluation of GMP cropping effects in terms of biodiversity.

\section{Lessons obtained from BINATS for future monitoring setups}

Aspects to be considered during the planning process of a GMP monitoring

The conception of a GMP monitoring program - selection of test areas, appropriate indicators, methods, farmers' clarification, etc. - should start far earlier than the GMP cropping. Importantly, the initial sampling design has to consider that farmers may deny work on their private properties. A total of 1,360 involved farmers were informed about the project BINATS. Sixty-nine of these denied work on their fields. Twenty-seven of the 100 preselected test areas were affected by this prohibition. Twenty-one of these test areas could be retained by shifting survey circles appropriately [48]. Six test areas had to be shifted as a whole along the Austrian forest inventory raster. However, sizes of Austrian farms are small (average farm size, 18.9 ha) [59] as compared to other EU countries, and problems with denied access may be more serious with larger farm sizes.

\section{Suitability of the selected indicators}

Habitat structures, vascular plants and grasshoppers proved to be excellent indicators in terms of practicability and cost efficiency. Vascular plants and grasshoppers showed high species numbers and abundances in most of the BINATS test areas, a circumstance which should enable the detection of potential species loss assumed from future GMP cultivation. Also, the methodology was practicable. One inspection for recording habitat structures and two inspections for monitoring vascular plants seemed to be adequate to get a comprehensive picture of diversity. Grasshoppers are mobile and their occurrence depends on weather conditions. One inspection proved to be marginal. When repeating the BINATS monitoring program, sampling frequency of grasshoppers should be increased to at least two annual surveys to provide comprehensive data.

Butterflies principally comply with the necessary requirements of an indicator for a case-specific monitoring as well as a general surveillance. Unfortunately, the BINATS budget allowed just one butterfly survey, which did not deliver satisfying results. Moreover, due to our strict methodological guidelines, the survey had to be cancelled and repeated if weather conditions exceeded specific thresholds (in temperature and wind force), which resulted in additional working time (repeated visit of the test area). Despite financial limits, we mainly chose that indicator because of its specific sensibility to Bt maize, which makes butterflies attractive as a GMP indicator. When repeating the BINATS monitoring program hopefully in a few years, the number of butterfly surveys should be increased. However, to do this within financial limits, we need to simplify some methodological aspects (e.g. just recording species numbers but no individual numbers). We suppose that at least five surveys per year would be needed to collect reliable quantitative data [60]. We conclude that butterflies are a standard in recording biodiversity programs including GMP monitoring. However, under serious financial restrictions, this indicator group cannot be satisfactorily monitored with the methodology used in BINATS.

Furthermore, we emphasise that if the BINATS monitoring program will be repeated, an additional indicator should be included. The inclusion of a soil-related taxon like ground beetles, soil mites, spiders, collembols, nematodes or earthworms would essentially improve the significance of the BINATS data. They reflect another compartment of biodiversity in agro-ecosystems. The methodology for one of these indicators could easily be adapted to the general survey design. The additional indicator group should be chosen before fixing the financial budget of the repeated BINATS circle in order to guarantee sufficient financial support.

\section{Effort in time and cost of such a monitoring program}

Recorded working times by the field surveyors allowed estimating the efforts associated with collecting data on the different indicators using the BINATS methodology. The average working time per test area (including preparation, excluding driving time) was $4.8 \mathrm{~h}$ for habitat structure mapping over the whole test area $(625 \mathrm{~m} \times$ $625 \mathrm{~m}$ ). Also, $4.8 \mathrm{~h}$ on average were spent on the survey of the butterflies on all ten test circles per test area. In comparison to other butterfly monitoring programs (e.g. BDM Switzerland, Butterfly Monitoring Germany), the time effort is high, which is mainly due to our strict methodical guidelines also concerning climatic thresholds and, in comparison to the other two mentioned projects, the fixed location of the BINATS transects. This $4.8 \mathrm{~h}$ survey included finding the location of the ten test circles, measuring the exact position of the test circles, justifying the cardinal points of the transect cross, marking the points of the transect cross with subjects like cloths, performing the survey along the transect cross, identifying habitats within the crosstransect, determining species within each habitat, and an additional control survey. In some cases when weather conditions changed - temperature and wind thresholds had to be abided - the test area had to be visited for a second time, which additionally consumed time. The survey time on the transect cross was from 10 to 20 min depending on the habitat type (e.g. bare fallow or highly structured habitats with higher abundance 
of butterflies). Additional 5 min were spent for a control survey, which means that the direct survey time for one test area (ten transect crosses) was between $2.5 \mathrm{~h}$ as a minimum and $4.17 \mathrm{~h}$ as a maximum, excluding the activities mentioned above. For vascular plants and for grasshoppers 5.7 and $7.2 \mathrm{~h}$, respectively were calculated, also including the additional activities listed for butterflies.

When the average driving time was included in the calculation, working time ran up to $6.7 \mathrm{~h}$ for habitat structure mapping, $6.8 \mathrm{~h}$ for butterflies, $7.6 \mathrm{~h}(\times 2)$ for vascular plants and up to $9.3 \mathrm{~h}$ for grasshoppers. Altogether, the survey of an average test area using the indicator-specific strict BINATS methodical guidelines plus driving time is estimated to be about $38 \mathrm{~h}$, which amounts to approximately one person week.

Not surprisingly, the efforts spent on a particular test area were dependent on the diversity of habitat structures or on the number of species present, respectively. For instance, working time for habitat structure mapping varied between $40 \mathrm{~min}$ in more or less homogeneous, intensively used landscapes and $10 \mathrm{~h}$ in complex, heterogeneous landscape mosaics.

\section{Conclusions}

BINATS is the first operational biodiversity monitoring network for agricultural landscapes in Austria and provides baseline data for three different taxonomic groups as well as for habitat structure diversity. The BINATS design was developed to identify and assess potential effects of eventual GMP cropping on biodiversity. However, it can also be used for a general monitoring of biodiversity trends in agricultural landscapes, e.g. for evaluating the efficiency of agro-environmental schemes. The BINATS design meets the requirements of a flexible monitoring system into which additional indicators and their particular survey needs can easily be integrated if necessary. In the case of a GMP release, extensive standardised baseline data on biodiversity for the indicators habitat structure, vascular plants, butterflies and grasshoppers are now available together with a representative set of adequate test areas.

\section{Recommendations and perspectives}

To assess biodiversity trends, regular reassessments of the BINATS data are needed. The underlying cost/benefit analysis guarantees that such reassessments will deliver informative data on biodiversity trends at comparatively low costs. But we emphasise that an additional soil indicator should be included into the survey procedure when repeating the BINATS monitoring program. The results obtained from the first BINATS cycle could not yet be correlated with GMP impacts since GMPs have not been commercially released in Austria so far. In this aspect, BINATS still needs to prove its suitability to relate biodiversity changes to GMP cropping.

It is still under discussion which changes in biodiversity caused by GMP cropping are considered as damage and which are not $[11,61,62]$. This is also an open question for future judgements of BINATS in the case of a GMP release. A definition of damage and a setting of thresholds (e.g. number of lost species) cannot be judged by scientists only, but is subject for an intercommunicative consensus finding between scientists and stakeholders.

\section{Acknowledgements}

The project BINATS was financially supported by the two Austrian Federal Ministries of Health and of Agriculture, Forestry, Environment and Water Management. We thank our Swiss colleagues for making the Swiss BDM field guides available to us (Hintermann \& Weber, Reinach). We are grateful to Helmut Höttinger for developing the butterfly monitoring design.

Furthermore, we cordially thank Manuel Denner, Roland Hainz, Karl Hülber, Anton Koschuh, Thomas Moertelmaier, Alexander Panrok, Christa Renetzeder, Alois Schmalzer, Rudolf Schmid, Ingrid Schmitzberger, Martin Strausz, Werner Weißmair and Wolfgang Willner for helping us with the field work and for improving the BINATS design. We thank our anonymous reviewers for helpful comments on a previous version of the manuscript.

\section{Author details}

${ }^{1}$ University of Vienna, Department of Conservation Biology, Vegetation Ecology and Landscape Ecology (CVL), Rennweg 14, A-1030 Vienna, Austria ${ }^{2}$ University of Natural Resources and Life Sciences, Institute of Zoology,

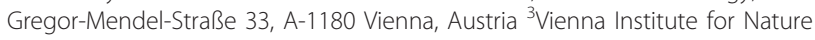
Conservation \& Analyses (VINCA), Giessergasse 6/7, A-1090 Vienna, Austria ${ }^{4}$ Büro für Naturschutzpraxis und Forschung, An der Scheibenwiese 1/1/2, A1160 Vienna, Austria ${ }^{5}$ Salzburg Biodiversity Centre, Museum House of Nature, Museumsplatz 5, A-5020 Salzburg, Austria ${ }^{6}$ Office BIOME, Lorenz Steinergasse 6, A-2201 Gerasdorf, Austria

\section{Authors' contributions}

KP conceived and organized this study, and managed the survey of the vascular plants, the butterflies and of habitat structures. DM and ST carried out all data analyses. LS organized the survey of the grasshoppers. PG, NS, TF, AT and GG contributed as scientific consultants. All authors participated in designing the BINATS monitoring program and most of them performed field work. KP, SD and DM wrote the paper. All authors read and approved the final manuscript.

\section{Competing interests}

The authors declare that they have no competing interests.

Received: 16 December 2010 Accepted: 14 March 2011 Published: 14 March 2011

\section{References}

1. Directive 2001/18/EC of the European Parliament and of the Council of 12 March 2001 on the deliberate release into the environment of genetically modified organisms and repealing Council Directive 90/220/ EEC - Commission Declaration, OJ L 106, 17.4. 2001, 1-39.

2. Council Decision 2002/811/EC of 3rd October: Establishing guidance notes supplementing Annex VII to Directive 2001/18/EC of the European Parliament and of the Council on the deliberate release into the environment of genetically modified organisms and repealing Council Directive 90/220/EEC. 2002.

3. Haughton AJ, Champion GT, Hawes C, Heard MS, Brooks DR, Bohan DA, Clark SJ, Dewar AM, Firbank LG, Osborne JL, Perry JN, Rothery P, Roy DB, Scott RJ, Woiwod IP, Birchall C, Skellern MP, Walker JH, Baker P, Browne EL, Dewar AJG, Garner BH, Haylock LA, Horne SL, Mason NS, Sands RJN, 
Walker MJ: Invertebrate responses to the management of genetically modified herbicide-tolerant and conventional spring crops II. Withinfield epigeal and aerial arthropods. Phil Trans R Soc Lond B 2003, 358:1863-1877.

4. Roy DB, Bohan DA, Haughton AJ, Hill MO, Osborne JL, Clark SJ, Perry JN, Rothery P, Scott RJ, Brooks DR, Champion GT, Hawes C, Heard MS, Firbank LG: Invertebrates and vegetation of field margins adjacent to crops subject to contrasting herbicide regimes in the Farm Scale Evaluations of genetically modified herbicide-tolerant crops. Philos Trans R Soc Lond B 2003, 358:1879-1898.

5. Bohan DA, Boffey CWH, Brooks DR, Clark SJ, Dewar AM, Firbank LG, Haughton AJ, Hawes C, Heard MS, May MJ, Osborne JL, Perry JN, Rothery P, Roy DB, Scott RJ, Squire GR, Woiwod IP, Champion GT: Effects on weed and invertebrate abundance and diversity of herbicide management in genetically modified herbicide-tolerant winter-sown oilseed rape. Proc $R$ Soc B 2005, 272:463-474.

6. Firbank LG, Heard MS, Woiwod IP, Hawes C, Haughton AJ, Champion GT, Scott RJ, Hill MO, Dewar AM, Squire GR, May MJ, Brooks DR, Bohan DA, Daniels RE, Osborne JL, Roy DB, Black HIJ, Rothery P, Perry JN: An introduction to the farm-scale evaluations of genetically modified herbicide-tolerant crops. J Appl Ecol 2003, 40:2-16.

7. Bühler C: Biodiversity monitoring in Switzerland: what can we learn for general surveillance on GM crops? J Verbr Lebensm 2006, 1 (Supplement 1):37-41.

8. Pascher $K$, Moser D, Dullinger S, Sachslehner L, Höttinger H, Traxler A, Sauberer N, Frank T, Grabherr G: Monitoring design to evaluate biodiversity in Austrian agricultural regions. In Implications of GM-Crop Cultivation at Large Spatial Scales Theorie in der Ökologie 14. Edited by: Breckling B, Reuter H, Verhoeven R. Frankfurt: Lang P; 2008:146-150.

9. Pascher K, Moser D, Dullinger S, Sachslehner L, Gros P, Traxler A, Sauberer N, Frank T, Grabherr G: Establishment of an Austrian monitoring design of genetically modified plants. Proceedings of the Fourth International Conference on Coexistence between Genetically Modified (GM) and Non-GM based Agricultural Supply Chains - GMCC09: 10-12 November 2009 Melbourne, Australia; 2009, 11.

10. Huston MA: Biological Diversity Cambridge: Cambridge University Press; 1994.

11. Heink U, Kowarik I: What criteria should be used to select biodiversity indicators? Biodivers Conserv 2010, 19:3769-3797.

12. Büchs W: Biodiversity and agri-environmental indicators - general scopes and skills with special reference to the habitat level. Agric Ecosyst Environ 2003, 98:35-78.

13. Meier MS, Hilbeck A: Faunistische Indikatoren für das Monitoring der Umweltwirkungen gentechnisch veränderter Organismen (GVO). Verfahren zur Beurteilung und Auswahl. Naturschutz und Biologische Vielfalt 29 Bonn: Bundesamt für Naturschutz; 2005, 332.

14. Thomas JA, Telfer MG, Roy DB, Preston CD, Greenwood JJD, Asher J, Fox R, Clarke RT, Lawton JH: Comparative losses of British butterflies, birds, and plants and the global extinction crisis. Science 2004, 303:1879-1881.

15. Thomas JA: Monitoring change in the abundance and distribution of insects using butterflies and other indicator groups. Proc R SOC B 2005, 360:339-357.

16. Hess GR, Bartel RA, Leidner AK, Rosenfeld KM, Rubino MJ, Snider SB, Ricketts TH: Effectiveness of biodiversity indicators varies with extent, grain, and region. Biol Conserv 2006, 132:448-457.

17. Rodrigues ASL, Brooks TM: Shortcuts for biodiversity conservation planning: the effectiveness of surrogates. Annu Rev Ecol Evol Syst 2007, 38:713-737.

18. Commission Decision 2010/135/EC of 2rd March (2010) Placing on the market, in accordance with Directive 2001/18/EC of the European Parliament and of the Council, of a potato product (Solanum tuberosum L., line EH92-527-1) genetically modified for enhanced starch content of the amylopectin component of starch (notified under document number K. 2010, 1193.

19. James C: Global Status of Commercialized Biotech/GM Crops: 2009. ISAAA Brief No. 41 ISAAA: Ithaca, NY; 2009.

20. Pessel FD, Lecomte J, Emeriau V, Krouti M, Messean A, Gouyon PH: Persistence of oilseed rape (Brassica napus L.) outside of cultivated fields. Theor Appl Genet 2001, 102:841-846

21. Crawley MJ, Brown SL: Spatially structured population dynamics in feral oilseed rape. Proc R Soc B 2004, 271:1909-1916.
22. Saji H, Nakajima N, Aono M, Tamaoki M, Kubo K, Wakiyama S, Hatase $Y$, Nagatsu M: Monitoring the escape of transgenic oilseed rape around Japanese ports and roadsides. Environ Biosafety Res 2005, 4:217-222.

23. Pivard S, Adamczyk K, Lecomte J, Lavigne C, Bouvier A, Deville A, Gouyon PH, Huet S: Where do the feral oilseed rape populations come from? A large-scale study of their possible origin in a farmland area. $J$ Appl Ecol 2007, 45:476-485.

24. Von der Lippe M, Kowarik I: Long-distance dispersal of plants by vehicles as a driver of plant invasions. Conserv Biol 2007, 21:986-996.

25. Kawata M, Murakami K, Ishikawa T: Dispersal and persistence of genetically modified oilseed rape around Japanese harbors. Environ Sci Pollut Res 2009, 16:120-126.

26. Nishizawa T, Nakajima N, Aono M, Tamaoki M, Kubo A, Saji H: Monitoring the occurrence of genetically modified oilseed rape growing along a Japanese roadside: 3-year observations. Environ Biosafety Res 2009, 8:33-44.

27. Pascher K, Macalka S, Rau D, Gollmann G, Reiner H, Glössl J, Grabherr G: Molecular differentiation of commercial varieties and feral populations of oilseed rape (Brassica napus L.). BMC Evol Biol 2010, 10:63.

28. Moser D, Zechmeister HG, Plutzar C, Sauberer N, Wrbka T, Grabherr G: Landscape shape complexity as an effective measure for plant species richness in rural landscapes. Landsc Ecol 2002, 17:657-669.

29. Steffan-Dewenter I, Münzenberg U, Bürger C, Thies C, Tscharntke T: Scaledependent effects of landscape context on three pollinator guilds. Ecology 2002, 83:1421-1432.

30. Thies C, Steffan-Dewenter I, Tscharntke T: Effects of landscape context on herbivory and parasitism at different spatial scales. Oikos 2003, 101:18-25.

31. Drapela T, Moser D, Zaller JG, Frank T: Spider assemblages in winter oilseed rape affected by landscape and site factors. Ecography 2008, 31:254-262.

32. Zaller JG, Moser D, Drapela T, Schmöger C, Frank T: Insect pests in winter oilseed rape affected by field and landscape characteristics. Basic Appl Ecol 2008, 9:682-690.

33. Schulze $\mathrm{CH}$, Waltert M, Kessler PJA, Pitopang R, Veddeler D, Mühlenberg M, Gradstein SR, Leuschner C, Steffan-Dewenter I, Tscharntke T: Biodiversity indicator groups of tropical land-use systems: comparing plants, birds, and insects. Ecol Appl 2004, 14:1321-1333.

34. Sætersdal M, Gjerde I, Blom HH, Ihlen PG, Myrseth EW, Pommeresche R, Skartveit J, Solhøy T, Aas O: Vascular plants as a surrogate species group in complementary site selection for bryophytes, macrolichens, spiders, carabids, staphylinids, snails, and wood living polypore fungi in a northern forest. Biol Conserv 2004, 115:21-31.

35. Wolters V, Bengtsson J, Zaitsev AS: Relationship among the species richness of different taxa. Ecology 2006, 87:1886-1895.

36. Sauberer N, Zulka K, Abensperg-Traun M, Berg H-M, Bieringer G, Milasowszky N, Moser D, Plutzar C, Pollheimer M, Storch C, Tröstl R, Zechmeister H, Grabherr G: Surrogate taxa for biodiversity in agricultural landscapes of eastern Austria. Biol Conserv 2004, 117:181-190.

37. Lang A: Monitoring the impact of Bt maize on butterflies in the field: estimation of required sample sizes. Environ Biosafety Res 2004, 3:55-66.

38. Kühn E, Feldmann R, Harpke A, Himeisen N, Musche M, Leopold P, Settele J: Getting the public involved in butterfly conservation: lessons learned from a new monitoring scheme in Germany. Isr J Ecol Evol 2008, 54:89-103.

39. van Swaay CAM, Nowicki P, Settele J, van Strien AJ: Butterfly monitoring in Europe: methods, applications and perspectives. Biodivers Conserv 2008, 17:3455-3469.

40. van Dyck H, van Strien AJ, Maes D, van Swaay CAM: Declines in common, widespread butterflies in a landscape under intense human use. Conserv Biol 2009, 23:957-965.

41. Schmeller DS, Henry P-Y, Julliard R, Gruber B, Clobert J, Dziock F, Lengyel S, Nowicki P, Déri E, Budrys E, Kull T, Tali K, Bauch B, Settele J, van Swaay C, Kobler A, Babij V, Papastergiadou E, Henle K: Advantages of volunteerbased biodiversity monitoring in Europe. Conserv Biol 2009, 23:307-316.

42. Losey JE, Rayor LS, Carter ME: Trangenic pollen harms monarch larvae. Nature 1999, 399:214-215.

43. Hansen Jesse LC, Obrycki JJ: Field deposition of Bt transgenic corn pollen: lethal effects on the monarch butterfly. Oecologia 2000, 125:241-248.

44. Hellmich RL, Siegfried BD, Sears MK, Stanley-Horn DE, Daniels MJ, Mattila HR, Spencer T, Bidne KG, Lewis LC: Monarch larvae sensitivity to 
Bacillus thuringiensis-purified proteins and pollen. Proc Nat Acad Sci USA 2001, 98:11925-11930.

45. Felke M, Lorenz N, Langenbruch GA: Laboratory studies on the effecs of pollen from Bt-maize on larvae of some butterfly species. J Appl Entomol 2002, 126:320-325.

46. Lang A, Vojtech E: The effects of pollen consumption of transgenic Bt maize on the common swallowtail, Papilio machaon L. (Lepidoptera, Papilionidae). Basic Appl Ecol 2006, 7:296-306.

47. Steffan-Dewenter I, Tscharntke T: Early succession of butterfly and plant communities on set-aside fields. Oecologia 1997, 109:294-302.

48. Pascher K, Moser D, Sachslehner L, Höttinger H, Sauberer N, Dullinger S, Traxler A, Frank T: Field guide for a biodiversity inventory in the agrarian region - vascular plants, butterflies, grasshoppers and habitat structures. Report under the authority of the Austrian Federal Ministries of Health, section II and of Agriculture, Forestry, Environment and Water Management Vienna, Austria; 2010, 50

49. Pascher K, Moser D, Traxler A, Frank T, Dullinger S, Sauberer N, Sachslehner L, Höttinger H, Grabherr G: Untersuchungsdesign zur Erfassung der Biodiversität in österreichischen Ackerbaugebieten. In GVO-Monitoring vor der Umsetzung. Naturschutz und Biologische Vielfalt 49. Edited by: Breckling B, Dolek M, Lang A, Reuter H, Verhoeven R. Münster: Landwirtschaftsverlag; 2007:33-43.

50. Essl F, Egger G, Ellmauer T: Rote Liste der gefährdeten Biotoptypen Österreichs. Wälder, Forste, Vorwälder. UBA-Monographien Band 156, Umweltbundesamt, Vienna; 2002, 104.

51. Essl F, Egger $G$, Karrer $G$, Theiss M, Aigner S: Rote Liste der gefährdeten Biotoptypen Österreichs. Grünland, Grünlandbrachen und Trockenrasen; Hochstauden- und Hochgrasfluren, Schlagfluren und Waldsäume; Gehölze der Offenlandschaft, Gebüsche. UBA-Monographien M167, Vienna; 2004, 272

52. Essl F, Egger G, Poppe M, Rippel-Katzmaier I, Staudinger M, Muhar S, Unterlercher M, Michor K: Rote Liste gefährdeter Biotoptypen Österreichs. Binnengewässer, Gewässer- und Ufervegetation, Technische Biotoptypen und Siedlungsbiotoptypen. Vienna: Neuer Wissenschaftlicher Verlag 2008, 316.

53. Traxler A, Minarz E, Englisch T, Fink B, Zechmeister H, Essl F: Rote Liste gefährdeter Biotoptypen; Biotoptypengruppen: Moore, Sümpfe und Quellfluren; Hochgebirgsrasen, Pionier-, Polster- und Rasenfragmente, Schneeböden; Äcker, Ackerraine, Weingärten und Ruderalfluren; Zwergstrauchheiden; Geomorphologische Biotoptypen. Monographien des Umweltbundesamtes, M-174 Vienna; 2005, 286.

54. Niklfeld H, Schratt-Ehrendorfer L: Rote Liste gefährdeter Farn- und Blütenpflanzen (Pteridophyta und Spermatophyta) Österreichs 2 Fassung. In Rote Listen gefährdeter Pflanzen Österreichs, 2. Auflage. Volume 10. Edited by: Niklfeld H. Vienna: Grüne Reihe BM Umwelt Jugend Familie: 1999:33-130.

55. Pascher K, Gollmann G: Ecological risk assessment of transgenic plant releases: an Austrian perspective. Biodivers Conserv 1999, 8:1139-1158.

56. Pascher $\mathrm{K}$, Macalka-Kampfer $\mathrm{S}$, Reiner $\mathrm{H}$ : Vegetationsökologische und genetische Grundlagen für die Risikobeurteilung von Freisetzungen von transgenem Raps und Vorschläge für ein Monitoring. Studie im Auftrag des Bundeskanzleramtes, Sektion IX, Bundesministerium für soziale Sicherheit und Generationen, Forschungsberichte 7/00 2000, 153+24.

57. Niklfeld H: Mapping the flora of Austria and the eastern Alps. Revue Valdotaine d'Histoire Naturelle 1998, 51(Suppl):53-62.

58. Traxler A, Minarz E, Höttinger H, Pennerstorfer J, Schmatzberger A, Banko G, Placer K, Hadrobolec M, Gaugitsch H: Biodiversitäts-Hotspots der Agrarlandschaft als Eckpfeiler für Risikoabschätzung und Monitoring von GVO. Forschungsberichte der Sektion IV, Band 5/2005 Vienna; 2005, 177.

59. Grüner Bericht: Bericht über die Situation der österreichischen Land- und Forstwirtschaft. Im Auftrag des Bundesministeriums für Land- und Forstwirtschaft. Umwelt und Wasserwirtschaft 2009 [http://www. gruenerbericht.at].

60. Bühler C: Wunsch und Wirklichkeit - Wie lässt sich ein GVO-Monitoring kosteneffizient realisieren? In GVO-Monitoring vor der Umsetzung Naturschutz und Biologische Vielfalt 49. Edited by: Breckling B, Dolek M, Lang A, Reuter H, Verhoeven R. Münster: Landwirtschaftsverlag; 2007:57-69.

61. Kowarik I, Bartz R, Heink U: Bewertung "ökologischer Schäden infolge des Anbaus gentechnisch veränderter Organismen (GVO) in der Landwirtschaft. Naturschutz und Biologische Vielfalt 56 Münster: Landwirtschaftsverlag; 2008, 248.
62. Bartz R, Heink U, Kowarik I: Proposed definition of environmental damage illustrated by the cases of genetically modified crops and invasive species. Conserv Biol 2010, 24:675-681.

63. Chevré A-M, Ammitzbøll H, Breckling B, Dietz-Pfeilstetter A, Eber F, Fargue A, Gomez-Campo C, Jenczewski E, Jørgensen R, Lavigne C, Meier MS, den Nijs HCM, Pascher K, Seguin-Swartz G, Sweet J, Stewart CN $\mathrm{Jr}$, Warwick S: A review on interspecific gene flow from oilseed rape to wild relatives. In Introgression from Genetically Modified Plants Into Wild Relatives. Proceedings of the Congress Introgression from Genetically Modified Plants Into Wild Relatives and its Consequences. Edited by: den Nijs HCM, Bartsch D, Sweet J. Wallingford: CABI Publishing; 2004:235-251.

64. Adler W, Oswald K, Fischer R: Bestimmungsbuch für alle in Österreich wildwachsenden sowie die wichtigsten kultivierten Gefäßpflanzen (Farnpflanzen und Samenpflanzen) mit Angaben über ihre Ökologie und Verbreitung. Exkursionsflora von Österreich Verlag Eugen Ulmer, Stuttgart und Wien; 1994, 1180.

65. Lafranchis T: Butterflies of Europe Paris: Diatheo; 2004, 351.

66. Tolman T, Lewington R: Die Tagfalter Europas und Nordwestafrikas Stuttgart: Kosmos Naturführer; 1998, 319.

67. Stettmer C, Bräu M, Gros P, Wanninger O: Die Tagfalter Bayerns und Österreichs. Laufen: ANL; 2 Auflage 2007, 248.

68. Harz K: Die Geradflügler Mitteleuropas Jena: Gustav Fischer Verlag; 1957, 494.

69. Bellmann H: Heuschrecken beobachten - bestimmen. 2 Auflage edition. Augsburg: Naturbuch-Verlag; 1993, 348.

70. Kocarek P, Holusa J, Vidlicka L: Blattaria, Mantodea, Orthoptera and Dermaptera of the Czech and Slovak Republics Zlin: Kabourek; 2005, 348.

71. Baur B, Baur H, Roesti C, Roesti D: Die Heuschrecken der Schweiz Bern: Haupt Verlag; 2006, 352.

doi:10.1186/2190-4715-23-12

Cite this article as: Pascher et al: Setup, efforts and practical experiences of a monitoring program for genetically modified plants an Austrian case study for oilseed rape and maize. Environmental Sciences Europe 2011 23:12.

\section{Submit your manuscript to a SpringerOpen ${ }^{\mathcal{O}}$ journal and benefit from:}

- Convenient online submission

- Rigorous peer review

- Immediate publication on acceptance

- Open access: articles freely available online

- High visibility within the field

- Retaining the copyright to your article

Submit your next manuscript at $\gg$ springeropen.com 